Proc. Estonian Acad. Sci. Geol., 1995, 44, 4, 211-220

\title{
DISCRETE DOLOMITE PHASES IN CARBONATE ROCKS: RESULTS OF THE MATHEMATICAL TREATMENT OF X-RAY DIFFRACTION PEAKS
}

\author{
Toivo KALLASTE and Tarmo KIIPLI
}

Eesti Teaduste Akadeemia Geoloogia Instituut (Institute of Geology, Estonian Academy of Sciences), Estonia pst. 7, EE-0001 Tallinn, Eesti (Estonia)

Presented by E. Pirrus

Received 24 March 1995, accepted 8 June 1995

Abstract. Dolomite was investigated by using the X-ray diffraction method to study 240 samples of variably dolomitized Ordovician and Silurian carbonate rocks from Estonia. It was established that dolomite $d_{104}$ values were from $2.885 \AA$ to $2.903 \AA$. Higher $d_{104}$ values occurred in samples containing calcite as well as in the samples taken near the edge of a dolostone body. The application of a resolution enhancement method (deconvolution) to these samples revealed the split-in-two shape of the reflection. The $d_{104}$ values and half-widths of both of the component-peaks were determined by the leastsquares curve-fitting method. As a result, two groups of dolomites with good crystallinity were distinguished: near-stoichiometric (normal) dolomites with $d_{104}$ values of $2.885-2.890 \AA$ and most likely calcian dolomites with $d_{104} 2.899-2.903 \AA$. Wide intermediate component-peaks can be associated with the normal dolomite group, where there appeared relationship between peak widening and $d$-value, but further studies should clarify this problem.

Key words: mineralogy, Palaeozoic dolomite, XRD analysis.

\section{INTRODUCTION}

The experimental work of Graf \& Goldsmith (1956) on the synthesis of mineral dolomite at high temperatures as well as later investigations of natural dolomites by the X-ray diffractometry (XRD) (Goldsmith \& Graf, 1958; Füchtbauer \& Goldschmidt, 1966) have allowed to conclude that dolomite may occur with variable structural state of ordering and may contain $50-57 \mathrm{~mol} \%$ (rarely up to $60 \mathrm{~mol} \%$ ) $\mathrm{CaCO}_{3}$. Numerous studies of various natural carbonates have confirmed this observation including previous work on the Palaeozoic carbonate rocks of Estonia (Вингисаар \& Утсал, 1978).

The occurrence of ideal stoichiometric sedimentary dolomite in postPalaeozoic rocks is an exception and a complete spectrum of compositional variations exists in Holocene samples (Land, 1980). From the Coorong region of South Australia dolomite with excess magnesium (approximately $4 \mathrm{~mol} \%$ ) in association with magnesite (Rosen et al., 1988) has been recorded. In some works dealing with older rocks the preferred compositions at near 51 and $56 \mathrm{~mol} \% \mathrm{CaCO}_{3}$ were mentioned (Reeder \& Sheppard, 1984). The sites of excess $\mathrm{Ca}$ in the dolomite structure are discussed in several papers (Goldsmith \& Graf, 1958; Lippmann, 1973; Reeder \& Sheppard, 1984; Ридер, 1987), but the problem is not solved yet. 
Some new information on this subject can be obtained through the mathematical treatment of diffractograms as used in the present investigation.

\section{MATERIAL}

Altogether 240 samples of dolostones, dolomitized limestones, and marls from the Ordovician, Silurian, and Devonian carbonate rocks of Estonia were investigated. Samples were collected from five localities that include a range of different environments of dolomite formation according to the interpretation of Kiipli (Кийпли, 1984).

1. Boreholes nearby the Aseri fault system in northeastern Estonia. Dolostones are recorded in the Middle Ordovician limestone sequence aligning the fault system for some hundred metres on both sides. This dolomite is interpreted to have formed by late diagenetic replacement. In the present paper the English terminology for diagenetic environments is used: early diagenetic in English corresponds to diagenetic in Russian literature, late diagenetic in English corresponds to catagenetic or epigenetic in Russian.

2. Boreholes near Oostriku, central Estonia, where occurrences of sulphide mineralization are reported. These dolomites range from late diagenetic (Middle Ordovician) to early diagenetic (Upper Ordovician and Silurian) types.

3. Boreholes in the eastern part of Saaremaa Island. A 40-100-mthick sequence of dolostones of shallow-water origin is known to occur in the upper Wenlock to lower Ludlow succession. The lateral extent of these dolostones is approximately $50 \mathrm{~km}$. Dolomitization stage: early diagenetic.

4. A quarry near Narva in northeastern Estonia which exposes the Middle Ordovician-Middle Devonian boundary beds. The Devonian samples consist of early diagenetic dolostone interbeds in dolomitic marls. In Ordovician limestones, a 0.2 -2-m-thick late diagenetic dolomite bed lies parallel to the unconformity O/D contact at $1-2 \mathrm{~m}$ below it.

5. Limestone, marl, and some dolostone samples were also collected within the stratigraphical interval extending from the upper Wenlock to Pridoli in the Ohesaare core, Saaremaa. The dolomite content in these rocks ranges from a few per cent to over $50 \%$.

\section{METHODS}

XRD measurements were carried out on a model HZG4 X-ray diffractometer (Freiberger Präzisionsmechanik), using Fe-filtered Co radiation. All samples were scanned in the range of 33 to 38 degrees including the 104 reflection of both calcite and dolomite. Pressed pellets, originally prepared for the XRF analysis, and containing a 1:1 mixture of rock powder and polystyrene were used in this study. The particle size of ground carbonates was $<10 \mu \mathrm{m}$ while the particle size of plastic was about $100 \mu \mathrm{m}$.

The pellets prepared in this way suit for the XRD analysis because of their smooth flat surfaces, but inconvenient aspects are the low absorption coefficient (polystyrene) and the uncontrolled orientation of particles in the surface layer because of pressure involved in the preparation of pellets. The measured positions of peaks were corrected for the diffractometer drift using the 111 silicon reflection from a standard pellet (consists of $1.5 \mathrm{~g}$ silicon, $2.5 \mathrm{~g}$ dolomite, and $4 \mathrm{~g}$ polystyrene), regularly measured in every $3-5$ samples. 
The measured diffractograms were treated using the general-purpose software. The integrated intensity and the centre of gravity of the 104 reflection of calcite and dolomite were found out. A least-squares curvefitting method was applied to the dolomite reflection giving the exact values for peak position and half-width. We used an asymmetric Lorentzian approach for the low-Ca dolomite $(d$-spacing $<2.893 \AA)$ and for the silicon reflection.

$$
I(2 \Theta)=I_{\max }\left(1+\left(\left(2 \Theta-2 \Theta_{\max }\right) / w\right)^{2}\right)^{-2},
$$

where parameter $w$ determines the width of the curve for both sides;

and

$$
w=w 1 \text {, if } 2 \Theta \leqslant 2 \Theta_{\max }
$$

$$
w=w 2 \text {, if } 2 \Theta>2 \Theta_{\max } .
$$

The formula contains four free parameters varied by the fitting program (peak position $2 \Theta_{\max }$, maximum intensity $I_{\max }$, width-determining parameters $w 1$ and $w 2)$. This profile matches well with the small instrumental asymmetry of XRD peaks caused by vertical divergence of the $\mathrm{X}$-ray beam and flat specimen aberrations, but it was clearly unsuitable for probably high-Ca dolomites ( $d$-spacing $>2.893 \AA$ ). In the last case two symmetric Lorentzian curves were used. In the fitting procedure, the used profile was calculated for both $K \alpha_{1}$ and $K \alpha_{2}$ lines.

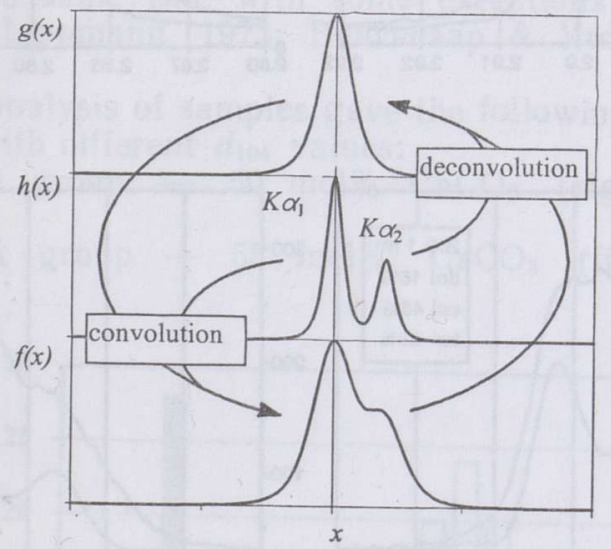

Fig. 1. The deconvolution model employed to the XRD reflection for the resolution enhancement: $g(x)$, actual peak shape (real crystal, ideal diffractometer); $h(x)$, apparatus function (ideal crystal, real diffractometer); $f(x)$, measured reflection profile.

The two-component nature of the dolomites with increased $d$-spacing was visualized by the Fourier deconvolution method for resolution enhancement (Fig. 1). We treated the measured peak profile $f(x)$ as a convolution of the actual peak-shape function $g(x)$ and the apparatus function $h(x)$

$$
f(x)=\int g(x) h(x-t) d t .
$$

The Fourier transform was employed to obtain the true peak profile (Fig. 2). The apparatus function (initial peak-shape function) for the procedure was constructed using the $K \alpha_{1}$ peak shape of the 111 silicon reflection (in asymmetric Lorentzian approach) and the calculated distance between $K \alpha_{1}$ and $K \alpha_{2}$ according to the dolomite reflection position. 

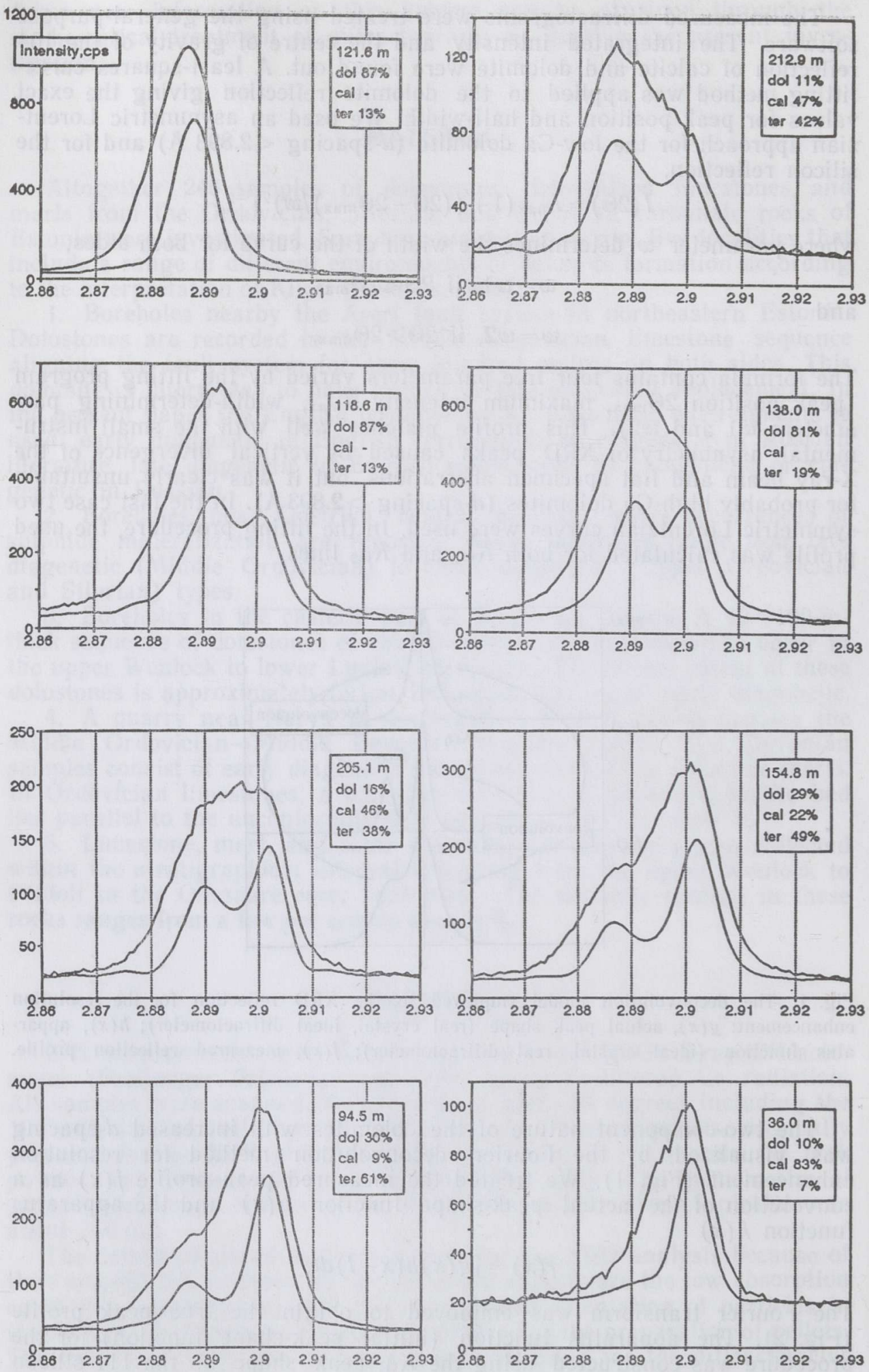

d-spacing, $\AA$ 
Fig. 2. X-ray diffractograms of different dolomites from the Ohesaare drill core. The measured and deconvoluted profiles of the 104 reflection are juxtaposed. Depth and main component percentages derived by XRF analysis are shown at the right top of each subgraph: dol, dolomite; cal, calcite; ter, terrigenous material.

Taking into account the XRD data, 13 samples of dolostone without calcite were analysed by titration: 5 with probably Ca-rich dolomite with the greatest $d$-spacing $(2.897-2.898 \AA)$ and 8 with the minimal $d$-spacing $(2.885-2.886 \AA)$, probably nearest to the stoichiometric double carbonate.

\section{RESULTS}

As a rule, the samples collected from large dolostone bodies do not contain calcite. The dolomite $d$-value varies from 2.886 to $2.890 \AA$ with the frequency maximum at $2.887 \AA$ (Fig. 3), independently of the interpreted dolomitization stage. This group includes the majority of samples from Saaremaa, Oostriku, and Aseri. The coexisting with calcite dolomite has an expanded crystal lattice (limestone and marl samples from the Ohesaare core). The same is observed in thin, less than $2 \mathrm{~m}$, dolostone layers (Narva quarry) and near the contact of dolostone with limestones in bigger bodies. The same rule with some exceptions was mentioned in previous works (Lippmann, 1973; Вингисаар \& Утсал, 1978; Кийпли, 1983).

The chemical analysis of samples gave the following average compositions for groups with different $d_{104}$ values:
a) $2.885-2.886$

b) $2.897-2.898 \AA$ group $-55 \mathrm{~mol} \% \mathrm{CaCO}_{3}$ (five samples, STD $0.5 \mathrm{~mol} \%)$.

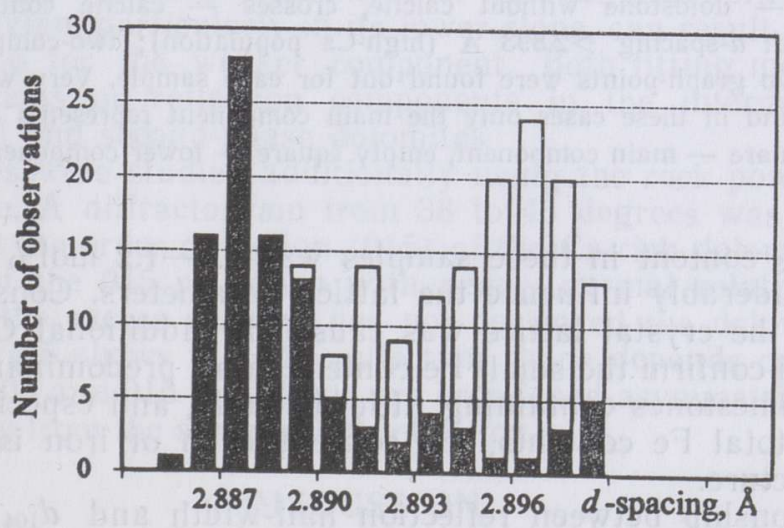

Fig. 3. Histogram showing the distribution of $d$-spacing of dolomite. $d$-spacings were calculated from the centre of gravity of the 104 reflection. Samples with a very weak reflection were excluded. Filled bars - pure dolostones (no calcite in the sample). Empty bars - calcite containing rocks (dolostones with calcite admixture, limestones, marls). 

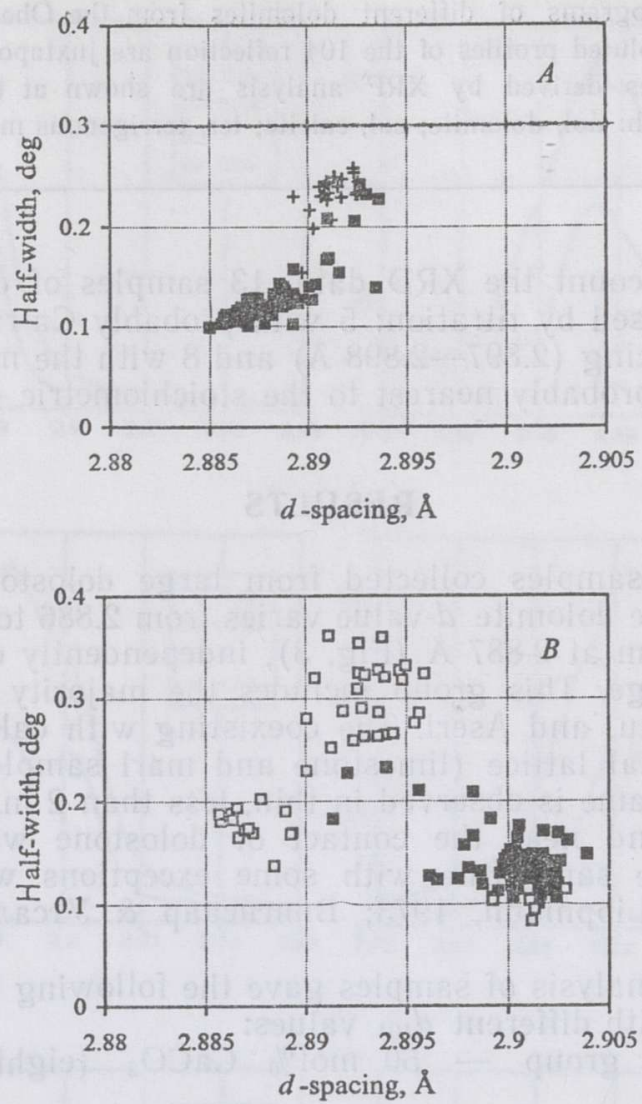

Fig. 4. Least-squares curve-fitting results for the 104 reflection of dolomite. $A$, dolomites with $d$-spacing $<2.893 \AA$ (low-Ca population); one-component approach was used. Filled squares - dolostone without calcite, crosses - calcite containing samples. $B$, dolomites with $d$-spacing $>2.893 \AA$ (high-Ca population); two-component approach was used, i.e. two graph-points were found out for each sample. Very weak components are not shown and in these cases only the main component represents a sample. Filled square - main component, empty square - lower component.

The $\mathrm{FeCO}_{3}$ content in these samples was $0.2-1.2 \mathrm{~mol} \%$ which is too small to considerably influence the lattice parameters. Consequently, the expansion of the crystal lattice was caused by additional $\mathrm{Ca}$ in it. XRF measurements confirm the small $\mathrm{Fe}$ content in all predominantly dolomitic samples. In limestones containing little dolomite, and especially in marls having high total $\mathrm{Fe}$ contents, the concentration of iron is unknown in dolomite structure.

The relationship between reflection half-width and $d_{104}$ is shown in Fig. 4. We distinguished the group of normal dolomites according to Fig. $4 A$ (half-width $<0.2 \mathrm{deg}$., $d$-spacing $<2.890 \AA$ ). There occurs positive correlation between these parameters in this group. The value $2.890 \AA$ for the upper border is arguable as dolomites from larger bodies had predominantly values below that, and the samples with higher values showed symptoms of structural heterogeneity.

Results of the two-component fitting of broad and asymmetric reflections are presented in Fig. 4B. The number of dominant component-peaks is larger than that of additional components because too weak components were excluded. The $d_{104}$ value of one of the component-peaks found by the 


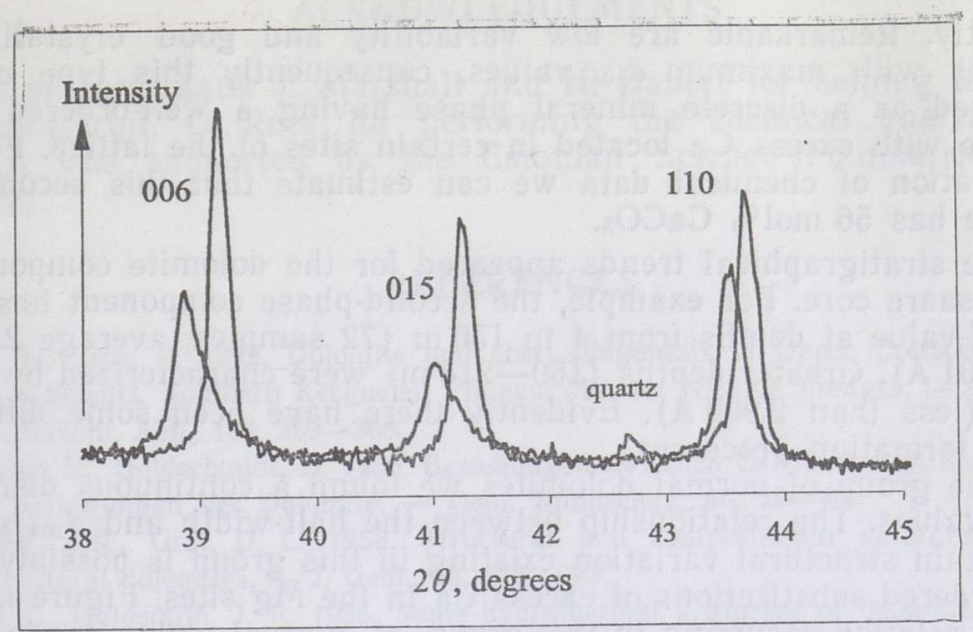

Fig. 5. Comparison of X-ray diffractograms of normal (higher peaks) and Ca-rich (lower peaks) dolomite. A reflection of quartz appears because of the terrigenous material in Ca-rich dolomite.

fitting program falls mostly into the interval between 2.898 and $2.903 \AA$. We distinguished the group of second-phase dolomite according to this plot (half-width $<0.2 \mathrm{deg}$., $d$-spacing ranges from 2.898 to $2.903 \AA$ ). This type of dolomite was found not to be a single dolomite phase in the investigated samples though it was mostly the main dolomite phase in limestones. Figure $2(36.0 \mathrm{~m})$ shows the nearly pure second-phase dolomite reflection. The placement of component-peaks with a smaller $d_{104}$ value in Fig. $4 B$ is similar to that in Fig. $4 A$, only half-widths are slightly larger. This can be related to their smaller intensity in the samples investigated because the imperfect match of the real XRD reflection profile with the Lorentzian, particularly in its lower slope, can result in a greater half-width value for the weaker component. Both fitting methods show broader reflections or reflection components in the intermediate area between normal and second-phase dolomites.

Five samples were studied additionally using the rock powder applied to a glass slide. A diffractogram from 38 to 45 degrees was scanned in order to control the order reflection (015) of the Ca-rich dolomite (Fig. 5). The presence of the 015 reflection with nearly normal relative intensity evidences that the excess calcium has not destroyed the dolomitic superstructure. Figure 5 shows that the reflection shape depends on the lattice direction. The 006 and 015 reflections are broadened asymmetrically differing significantly from the sharper 110 reflection.

\section{DISCUSSION}

Natural dolomites differ often from stoichiometric $\mathrm{Ca}-\mathrm{Mg}$ double carbonate. Several works present data showing bimodal frequency distribution of the $\mathrm{Ca}$ content in dolomites (Goldsmith \& Graf, 1958; Füchtbauer \& Goldschmidt, 1966). The preferred values are $50-52$ and $55-56 \mathrm{~mol}^{\%} \mathrm{CaCO}_{3}$. The bimodal distribution becomes evident also in XRD measurements, since additional $\mathrm{Ca}$ enlarges lattice parameters (Reeder \& Sheppard, 1984). In some works split XRD reflections are mentioned (Goldsmith \& Graf, 1958; Shatkay \& Magaritz, 1987).

The results of the present work are in good accordance with previous studies. The methods used allow us to investigate the preferred phases 
differently. Remarkable are low variability and good crystallinity of dolomites with maximum $d_{104}$ values, consequently this type could be considered as a discrete mineral phase having a well-ordered crystal structure with excess $\mathrm{Ca}$ located in certain sites of the lattice. From the extrapolation of chemical data we can estimate that this second-phase dolomite has $56 \mathrm{~mol} \% \mathrm{CaCO}_{3}$.

Some stratigraphical trends appeared for the dolomite components in the Ohesaare core. For example, the second-phase component has a very stable $d$-value at depths from 4 to $150 \mathrm{~m}$ (72 samples, average $2.9013 \AA$, STD $0.001 \AA)$. Greater depths $(150-218 \mathrm{~m})$ were characterized by smaller values (less than $2.900 \AA$ ). Evidently there have been some differences in rock formation processes.

In the group of normal dolomites we found a continuous distribution of $d_{104}$ values. The relationship between the half-width and $d_{104}$ suggests that certain structural variation existing in this group is possibly caused by disordered substitutions of excess $\mathrm{Ca}$ in the $\mathrm{Mg}$ sites. Figure $4 A$ shows that the relation occurring in the group of normal dolomites continues with the increasing of $d$-spacing beyond the group border and possibly includes wide intermediate component-peaks in Fig. $4 B$ as well. The last ones could be related to the greatest rate of disordered additional $\mathrm{Ca}$ in investigated dolomites. Reeder \& Sheppard (1984) found that variations in the $\mathrm{Ca}$ content from 50 to $52 \mathrm{~mol} \%$ did not affect lattice parameters. Thus, the problem remains unresolved.

Our results confirm the view mentioned by Lippmann (1973) and Hardie (1987) that dolomites having intermediate $d_{104}$ values are mixtures of different stable phases, but there seem to exist also dolomites with intermediate $d_{104}$ as a single phase.

According to literature data, the mixtures of different dolomite types can occur in two forms:

1. Mixtures of dolomite from different crystal growth stages appearing in the form of zoned crystals (Pierson, 1981; Morrow, 1982; Randazzo \& Cook, 1987; Bassias \& Cros, 1992). Inner zones are predominantly Ca-rich and outer rims have a nearly ideal composition, however in some cases the opposite succession was established. More rarely up to six different growth zones were found (Pierson, 1981).

2. A mixture of microcrystals appearing in the form of modulated and ribbon microstructures. This phenomenon is very typical of Ca-rich dolomites and absent in stoichiometric specimens (Венк et al., 1987; Reeder, 1992).

The connection of the dolomite composition with the mineral precipitation environment has attracted the attention of scientists for a long time. Füchtbauer \& Goldschmidt (1966), Lumsden \& Chimahusky (1980), and Morrow (1982) showed statistically that a higher $\mathrm{Mg}$ content in dolomite corresponds to higher salinity and $\mathrm{Mg} / \mathrm{Ca}$ ratio in water from which dolomite forms. The last author pointed out the role of the precipitation rate: very slowly growing crystals are closer to the stoichiometric composition. The positive correlation between the $\mathrm{Mg} / \mathrm{Ca}$ ratio in the solution and in experimentally precipitated $\mathrm{Ca}-\mathrm{Mg}$ carbonate was shown by Sibley et al. (1994).

Considering the results of the present work, it is evident that greater success in the research of dolomite genesis can be achieved by analysing different dolomite phases separately. Quite promising is detailed sampling of different rock components as small samples $(0.1 \mathrm{~g})$ can be used in XRD measurements. This possibly allows to separate in some cases dolomite phases prior to laboratory measurements. The method developed in the present paper is especially useful for analysing fine-crystalline rocks where other separation methods do not work. 


\section{ÁCKNOWLEDGEMENTS}

The authors thank J. Marshall and H. Bauert for helping to prepare the manuscript, 0 . Roos for performing the chemical analyses. This research was supported by the Estonian Science Foundation (grant No. 949).

\section{REFERENCES}

Bassias, Y., Cros, P. 1992. Dolomite and chert diagenesis in Upper Cretaceous pelagic sediments, Southern Kerguelen Plateau. MD 44: NASKA dredges. - N. Jb. Geol. Paläont. Abh., 184, 359-388.

Füchtbauer, H., Goldschmidt, H. 1966. Beziehungen zwischen Calciumgehalt und Bildungsbedingungen der Dolomite. - Geol. Rundschau, 55, 29-40.

Goldsmith, J. R., Graf, D. L. 1958. Structural and compositional variations in some natural dolomites. - J. Geol., 66, 678-693.

Graf, D. L., Goldsmith, J. R. 1956. Some hydrothermal syntheses of dolomite and protodolomite. - J. Geol., 64, 173-186.

Hardie, L. A. 1987. Dolomitization: A critical view of some current views. - J. Sed. Petrol., 57, 166-183.

Land, L. S. 1980. The isotopic and trace element geochemistry of dolomite: The state of the art. - SEPM Spec. Publ., 28, 87-110.

Lippmann, F. 1973. Sedimentary Carbonate Minerals. Springer-Verlag, Berlin. Heidelberg. New York.

Lumsden, D. N., Chimahusky, J. S. 1980. Relationship between dolomite nonstoichiometry and carbonate facies parameters. - In: Zenger, D. H., Dunham, J. B., Ethington, R. L. (eds.). Concepts and Models of Dolomitization. SEPM Spec. Publ., $28,123-137$.

Morrow, D. W. 1982. Diagenesis 2. Dolomite - part 2. Dolomitization models and ancient dolostones. - Geoscience Canada, 9, 2, 95-107.

Pierson, B. J. 1981. The control of cathodoluminescence in dolomite by iron and manganese. - Sedimentology, 28, 601-610.

Randazzo, A. F., Cook, D. J. 1987. Characterization of dolomitic rocks from the coastal mixing zone of the Floridan aquifer, Florida, U.S.A. - Sed. Geol., 54, 169-192.

Reeder, R. J., Sheppard, Ch. E. 1984. Variation of lattice parameters in some sedimentary dolomites. - Amer. Mineralogist, 69, 520-527.

Reeder, R. J. 1992. Carbonates: Growth and alteration microstructures. - In: Buseck, P. R. (ed.). Minerals and Reactions at the Atomic Scale: Transmission Electron Microscopy. Rev. Mineral., 27, 381-424.

Rosen, M. R., Miser, D. E., Warren, J. K. 1988. Sedimentology, mineralogy and isotopic analysis of Pellet lake, Coorong region, South Australia. - Sedimentology, 35, $105-122$.

Shatkay, M., Magaritz, M. 1987. Dolomitization and sulfate reduction in the mixing zone between brine and meteoric water in the newly exposed shores of the Dead Sea. - Geochim. Cosmochim. Acta, 51, 1135-1141.

Sibley, D. F., Nordeng, S. H., Borkowski, M. L. 1994. Dolomitization kinetics in hydrothermal bombs and natural settings. - J. Sediment. Res., A64, 630-637.

Венк Х. Р., Барбер Д. Дж., Ридер Р. Дж. 1987. Микроструктуры карбонатных минералов. - In: Ридер Р. Дж. (еd.). Қарбонаты: минералогия и химия. Мир, Москва, $371-445$.

Вингисаар П., Утсал К. 1978. О породообразующих карбонатных минералах палеозоя Эстонии. - Сов. геология, 12, 107-115.

Қийпли Т. 1983. Доломиты в Вяоской свите среднего ордовика Эстонии. - Изв. АН ЭССР. Геол., 32, 2, 60-68.

Кийпли Т. 1984. Генезис и распространение промышленных залежей малопримесных известняков и доломитов в Эстонской ССР. Автореф. канд. дис. Таллинн.

Ридер Р. Дж. (еd.). 1987. Карбонаты: минералогия и химия. Мир, Москва. 


\title{
DOLOMIIDI DISKREETSED FAASID KARBONAATKIVIMITES KUI RÖNTGENDIFRAKTOGRAMMI REFLEKSIDE MATEMAATILISE TÖÖTLUSE TULEMUS
}

\author{
Toivo KALLASTE, Tarmo KIIPLI
}

Mineraali dolomiit uuriti röntgendifraktsioonmeetodil 240-s ordoviitsiumi ja siluri karbonaatkivimi proovis. Dolomiidi kristallvõre aatomtasandite vahekaugus $d_{104}$ varieerus 2,885 kuni $2,903 \AA$. Suuremad $d_{104}$ väärtused ilmnesid kaltsiiti sisaldavates kivimites või juhul, kui dolokivi proov oli võetud lubjakivi kontakti lähedusest. Nendes proovides tõi dekonvolutsioonimeetod esile refleksi kahestumise. Kummagi komponendi $d_{104}$ väärtused ja poollaiused määrati kahekomponendise lähendamise meetodil. Tulemusena eristusid kaks gruppi hea kristalliinsusega dolomiite normaaldolomiidid $\left(d_{104} 2,885-2,890 \AA\right)$ ja tõenäoliselt kaltsiumirikkad dolomiidid $\left(d_{104} 2,899-2,903 \AA\right)$. Madalama kristalliinsusega vahepealsete faaside olemus vajab edasist uurimist.

\section{ДИСКРЕТНЫЕ ФАЗЫ ДОЛОМИТА В КАРБОНАТНЫХ ПОРОДАХ РЕЗУЛЬТАТЫ МАТЕМАТИШЕСКОИ ОБРАБОТКИ РЕНТГЕНОВСКОИ ДИФРАКТОГРАММЫ}

\section{Тойво КАЛЛАСТЕ, Тармо КИЙПЛИ}

Методом рентгеновской дифракции изучен доломит в 240 образцах ордовикских и силурийских карбонатных пород Эстонии. Установлена вариация межплоскостного расстояния $d_{104}$ от 2,885 до $2,903 \AA$. Более высокие значения характерны для образцов, содержащих, кроме доломита, и кальцит, а также для образцов, отобранных недалеко от границы доломитовой породы с известняками. Фурье-анализ выявил в этих образцах раздвоенное отражение. Величины межплоскостного расстояния и полуширины для двух рефлексов-компонентов получены методом двухкомпонентного приближения. В результате выявлено две группы доломитов с высокой степенью кристалличности - нормальные доломиты $\left(d_{104} 2,885-2,890 \AA\right)$ и, вероятно, богатые кальцием доломиты $\left(d_{104} 2,899-2,903 \AA\right)$. Природа промежуточных фаз с низкой кристалличностью требует дальнейшего исследования. 